\title{
\begin{tabular}{l|l|l} 
Jurnal Eksplorasi Akuntansi \\
Vol. 1, No 3, Seri E, Agustus 2019, Hal 1443-1457
\end{tabular} \mid $\begin{aligned} & \text { ISSN : 2656-3649 (Online) } \\
& \text { http://jea.ppj.unp.ac.id/index.php/jea/issue/view/12 }\end{aligned}$
}

\section{PENGARUH AKUNTABILITAS, KESESUAIAN KOMPENSASI DAN PENGENDALIAN INTERN TERHADAP POTENSI KECURANGAN DANA DESA}

\author{
Melisa Eka Sari ${ }^{1}$, Fefri Indra Arza², Salma Taqwa ${ }^{2}$ \\ 1) Alumni Jurusan Akuntansi Fakultas Ekonomi, Universitas Negeri Padang \\ ${ }^{2,3)}$ Jurusan Akuntansi Fakultas Ekonomi, Universitas Negeri Padang \\ *Korespondensi: mellisaekasari@gmail.com
}

\begin{abstract}
Abstracs: This research aim to determine the effect of accountability, suitability of compensation and intern control. Type of this research on causality. The population in this study was in village at Lima Puluh Kota.This research uses the total sampling technique so that the entire population in used as the research sample. The data scource is primary data. Methods of collecting data by distributing questionnaires. The result of the research concluded that accountability, suitability of compensation had a significant negative effect and internal control had a significant positive effect on potential fraud.
\end{abstract}

Keywords: Akuntabilitas; Dana Desa; Kesesuaian Kompensasi; Pengendalian Intern; Potensi Kecurangan

How to cite (APA $6^{\text {th }}$ style)

Sari, M. E., Arza, F. I., \& Taqwa, S. (2019). Pengaruh Akuntabilitas, Kesesuaian Kompensasi dan Pengendalian Intern Terhadap Potensi Kecurangan Dana Desa. Jurnal Eksplorasi Akuntansi, 1(3), Seri E, 1443-1457.

\section{PENDAHULUAN}

Adanya dana desa pemerintah berharap pelayanan publik di desa semakin meningkat, masyarakat desa maju dan berdaya, dan yang paling penting desa menjadi subjek pembangunan. Selain mengukur capaian dan dampak positif dana desa, permasalahan yang muncul dan tantangan kedepan harus menjadi pokok pembahasan yang serius. Hal ini penting dilakukan untuk memastikan harapan dan langkah kongkrit pemerintah tidak digembosi oleh persoalan misalnya kecurangan terhadap dana desa tersebut.

Korupsi di dana desa merupakan salah satu masalah mendasar disebabkan karena anggaran yang besar namun implementasi di level desa tidak di iringi transparasi, akuntabilitas, partisipasi dalam tata kelola politik, pembangunan, dan keuangan desa. Dari Tahun 2015-2017 korupsi di dana desa ditemukan sebanyak 154 kasus korupsi anggaran dana desa dengan beragam modus korupsi dana desa diantaranya praktik penyalahgunaan anggaran, penggelapan, laporan fiktif dan penggelembungan anggaran. Korupsi di dana desa menyebabkan kerugian negara dengan total Rp47,56 milyar (antikorupsi.org) 
Penggunaan dana desa di Sumatera Barat jadi perhatian Komisi Pemberantasan Korupsi (KPK) karena dana tersebut rentan diselewengkan. "seluruh wali nagari di daerah ini fokus jadi perhatian KPK". Hal itu dikemukakan juru bicara KPK Febri Diansyah dalam satu acara di Universitas Negeri Padang (Kompasiana.com). Puluhan wali nagari di Kabupaten Limapuluh Kota dikumpulkan oleh tim Pengawal dan Pengamanan Pemerintahan dan Pembagunan Daerah (TP4D) Kamis tanggal 24 Agustus 2017. Hal itu dilakukan dalam menghindari penyelewengan serta penyalahgunaan dana desa (nagari) oleh pemerintahan nagari setelah sebelumnya beberapa walinagari diperhentikan dari jabatan karena melakukan korupsi dana desa dan akan di proses secara hukum (harianhaluan.com). Isu ini menjadi penting karena riset Agustin et.al (2017) di kabupaten Pasaman Barat menemukan bahwa 78,57\% nagari di kabupaten Pasaman Barat yang telah memiliki kesadaran tinggi untuk mempublikasikan penggunaan anggaran nagari pada media massa maupun radio komunitas

Penelitian Oktaviani (2017) menjelaskan bahwa akuntabilitas berpengaruh negatif dan signifikan terhadap potensi kecurangandalam pengelolaan keuangan desa. Penelitian Sanuari (2014) menjelaskan bahwa sistem pengendalian intern dan kesesuaian kompensasi berpengaruh negatif terhadap kecendrungan kecurangan akuntansi. Perbedaan penelitian ini dengan penelitian terdahulu terletak pada sampel yang diambil, penambahan variabel independen akuntabilitas serta tempat dan waktu penelitian yang berbeda. Penelitian ini penting dilakukan di Kabupaten Lima Puluh Kota berdasarkan kasus yang telah disebutkan diatas.

Dari uraian tersebut, dengan ini penulis tertarik melakukan penelitian guna menguji apakah akuntabilitas, kesesuaian kompensasi dan pengendalian intern berpengaruh terhadap Potensi Kecurangan Dana Desa, Selanjutnya Penelitian Ini Diberi Judul "Pengaruh Akuntabilitas, Kesesuaian Kompensasi Dan Pengendalian Intern Terhadap Potensi Kecurangan Dana Desa (Studi Empiris Pada Desa di Kapubaten Lima Puluh Kota)”.

\section{REVIU LITERATUR DAN HIPOTESIS}

\section{Teori Agensi}

Menurut Anthony dan Govindarajan (2007: 530) konsep keagenan adalah hubungan atau kontrak antara principal dan agen agent. Principal memperkejakan agent untuk bertindak sesuai dengan kepentingan principal, namun principal dan agent mempunyai perbedaan prefensi dan tujuan. Dalam perusahaan (organisasi sektor bisnis) pemegang saham atau atasn bertindak sebagai principal, dan chief executive officer (CEO) dan bawahan sebagai agent mereka.Dalam organisasi sektor publik, atasan bertindak sebagai principal, dan bawahan sebagai agent mereka.

Pada organisasi sector publik dibangun atas dasar teori agensi. Teori agensi memandang bahwa pemerintah desa yaitu kepala desa dan aparat desa lainnya sebagai agents bagi masyarakat desa (principal) akan bertindak dengan penuh kesadaran bagi kepentingan mereka sendiri. Hubungan kontrak yang dimaksud adalah pendelegasian wewenang kepada agents untuk melakukan semua pekerjaan secara bertanggungjawab kepada pemerintah yang telah membuat Permendagri Nomor 113 tahun 2014 tentang Pengelolaan Keuangan Desa dan menjadi perpanjang dari masyarakat desa sebagai pemberi amanah dalam pelaksanaan tugas.

Berdasarkan teori agensi, pengelolaan keuangan desa harus di awasi untuk memastikan bahwa pengelolaan dana desa dilakukan dengan penuh kepatuhan kepada berbagai peraturan dan ketentuan yang berlaku seperti Peraturan Menteri Dalam Negeri Nomor 113 tahun 2014. 


\section{Kecuragan}

Definisi fraud menurut Blaks Law Dictionary yang dikutip oleh Karyono (2013:4) adalah "Kecurangan mencakup segala macam yang dapat dipikirkan manusia dan yang diupayakan oleh seseorang untuk mendapatkan keuntungan dari orang lain dengan saran yang salah atau memaksakan kebenaran dan mencakup semua cara yang tak terduga, penuh siasat, licik, tersembunyi dan setiap cara yang tidak jujur yang menyebabkan orang lain tertipu".

Tunggal (1992) mengatakan kecurangan (fraud) secara singkatnya dinyatakan sebagai suatu penyajian palsu atau penyembunyian fakta material yang menyebabkan seseorang memiliki sesuatu.Kecurangan merupakan suatu perbuatan yang bertentangan dengan kebenaran yang dilakukan dengan sengaja, dengan tujuan untuk memperoleh sesuatu yang bukan merupakan haknya. Berdasarkan uraian diatas dapat disimpulkam bahwa fraud merupakan sebuah tindakan yang menyebabkan kesalahan pelaporan dalam laporan keuangan, atau suatu tindakan yang tidak wajar yang dilakukan secara sengaja untuk memperoleh keuntungan pribadi, dan tindakan tersebut merupakan tindakan yang bertentangan dengan kebenaran, oleh karena itu fraud harus dicegah sedini mungkin agar tidak ada pihak yang dirugikan.

Jenis-Jenis kecurangan adalah (1) penyalahgunaan asset (2) kecurangan laporan keuangan dan (3) korupsi. Pencegahan kecurangan merupakan segala upaya untuk menangkal pelaku potensial, mempersempit ruang gerak, dan mengidentifikasi kegiatan yang berisiko tinggi terjadinya kecurangan(Karyono, 2013:47). Kecuranganmerupakan suatu masalah yang ada didalam perusahaan yang harus dicegah sedini mungkin, jika kecurangan tidak bisa dicegah maka perusahaan bisa mengalami kerugian bahkan kebangkrutan, oleh karena itu manajemen perusahaan harus mengambil tindakan yang tepat agar perusahaan terhindar dari kecurangan

Amrizal (2004:5) menyatakan ada empat cara yang dilakukan untuk mencegah kecurangan, yaitu membangun sistem pengendalian internal yang baik, mengefektifkan aktivitas pengendalian, meningkatkan kultur organisasi, dan mengefektifkan fungsi audit internal

\section{Dana Desa}

Dana desa adalah dana APBN yang diperuntukkan bagi desa yang ditransfer melalui APBD kabupaten/kota dan diprioritaskan untuk pelaksanaan pembangunan dan pemberdayaan masyarakat desa. Dana desa dihitung berdasarkan jumlah desa dan dialokasikan dengan memperhatikan jumlah penduduk, angka kemiskinan, luas wilayah dan tingkat kesulitan geografis. Menurut Undang-Undang No 6 Tentang Desa menyebutkan tujuan dana desa adalah untuk meningkatkan pelayan publik di desa, mengatasi kemiskinan, memujan perkenomian desa, mengatasi kesenjangan pembangunan antar desa, serta memperkuat masyarakat desa sebagai subjek dari pembangunan.

Dana desa diperuntukkan bagi desa dan desa adat yang di transfer melalui APBD Kabupaten/Kota dan di alokasikan secara adil dan merata kepada setiap desa yang telah dihitung berdasarkn proporsi dan formuladana desa. Salah satu aspek penting dalam pelaksanaan dan desa adalah penyaluran dana desa dari APBN ke Pemerintah Desa. Untuk mewujudkan prinsip transparasi dan akuntabilitas serta memastikan capaian penggunaan dan desa, proses persyaratan dana desa mempersyaratkan beberapa kriteria yang harus dipenuhi oleh Pemerintah Kabupaten/Kota yang diatur melalui Peraturan Menteri Keuangan No. 50/PMK.07/2017.

Prinsip penggunaan dana desa adalah keadilan, kebutuhan prioritas, kewenangan desa, partisipatif, swakelola dan berbasir sumber daya serta tipologi desa. pengelolaan dana desa di desa menjadi aspek penting dan mendasar yang harus dimiliki oleh para pemangku kepentingan di level pemerintah desa, khususnya perangkat desa dalam mewujudkan transparasi dan 
akuntabilitas dana desa. Pengelolaan keuangan desa meliputi perencanaan, pelaksanaan, penatausahaan, pelaporan dan pertangungjawaban keuangan desa.Asas pengelolaan keuangan desa tersebut adalah transparan, akuntabilitas, partisipatif, tertib disiplin dan anggaran

\section{Akuntabilitas}

Dalam pandangan Mardiasmo (2006), ada tiga pilar utama yang menjadi prasyarat terbangunnya akuntabilitas. Pertama, adanya transparansi para penyelenggara pemerintahan dalam menetapkan kebijakan publik dengan menerima masukan dan mengikutsertakan berbagai institusi. Kedua, adanya standar kinerja di setiap institusi yang dapat diukur dalam melaksanakan tugas, fungsi, dan wewenangnya. Ketiga, adanya partisipasi untuk saling menciptakan suasana kondusif dalam menciptakan pelayanan masyarakat dengan prosedur yang mudah, biaya yang murah, dan pelayanan yang cepat.

Menurut Elwood (1993) dalam Kurnia (2014) menjelaskan terdapat empat dimensi akuntabilitas yang harus dipenuhi oleh organisasi sektor publik yaitu :

1. Akuntabilitas Kejujuran dan Hukum (accountability for probity and legality)

Akuntabilitas kejujuran dan hukum (accountability for probity and legality) terkait dengan penyalahgunaan jabatan, sedangkan akuntabilitas hukum terkait dengan jaminan kepatuhan terhadap hukum dan peraturan lain yang disyaratkan dalam penggunaan sumber dana publik.

2. Akuntabilitas Proses (process accountability)

Akuntabilitas proses terkait dengan apakah prosedur yang digunakan dalam melaksanakan tugas sudah cukup baik dalam hal kecukupan sistem informasi akuntansi, sistem informasi manajemen dan prosedur akuntansi.

3. Akuntabilitas Program (program accountability)

Akuntabilitas program terkait dengan pertimbangan apakah tujuan yang ditetapkan dapat dicapai atau tidak, dan apakah telah mempertimbangkan alternatif program yang memberikan hasil yang optimal dengan biaya yang minimal

4. Akuntabilitas Kebijakan (policy accountability)

Akuntabilitas kebijakan terkait dengan pertanggungjawaban pemerintah, baik pusat maupun daerah, atas kebijakan kebijakan yang diambil pemerintah terhadap DPR, DPRD dan masyarakat luas

\section{Kesesuaian Kompensasi}

Menurut Veithzal (2006: 741) kompensasi merupakan sesuatu yang diterima karyawan sebagai pengganti kontribusi jasa mereka pada perusahaan. Pemberian kompensasi merupakan salah satu pelaksaan fungsi MSDM yang berhubungan dengan semua jenis pemberian penghargaan individual sebagai pertukaran dalam melakukan tugas keorganisasian. Kompensasi merupakan biaya utama atas keahlian atau pekerjaan dan kesetiaan dalam bisnis perusahaan.

Menurut Veithzal (2006) dalam Sanuari (2014), kompensasi yang diberikan kepada karyawan terdiri dalam dua bentuk yaitu :

a. Kompensasi yang bersifat finansial

Bentuk kompensasi ini ada dua macam, yaitu, kompensasi langsung, terdiri dari pembayaran karyawan dalam bentuk upah, gaji, bonus, atau komisi. Kompensasi tidak langsung atau benefit, terdiri dari semua pembayaran yang tidak tercakup dalam kompensasi finansial langsung yang meliputi liburan, berbagai macam asuransi, jasa seperti perawatan anak atau kepedulian keagamaan, dan sebagainya. 
b. Kompensasi yang bersifat non financial

Bentuk kompensasi ini seperti pujian, menghargai diri sendiri, promosi jabatan, dan pengakuan yang dapat mempengaruhi motivasi kerja karyawan, produktifitas, dan kepuasan.

\section{Pengendalian Intern}

Menurut committee of the American Institute of Accountants (AICPA) dalam Sanuari (2014) defenisi pengendalian internal adalah rencana organisasi dan semua metode serta ketentuan yang terkoordinasi yang dianut perusahaan untuk melindungi harta miliknya, mengecek kecermatan dan keandalan data akuntansi, peningkatan efisiensi usaha, dan mendorong ditaati kebijakan manajemen yang di terapkan. Konsep dalam pengendalian intern adalah kebijakan dan prosedur yang ditetapkan untuk memberikan jamninan bahwa tujuan khusus organisasi dapat dicapai.Struktur pengendalian intern terdiri dari tiga elemen yaitu lingkungan pengendalian, sistem akuntansi dan prosedur pengendalian.Keandalan dan ketelitian catatan akuntansi ditentukan oleh tiga elemen struktur pengendalian.

Ada dua pendekatan sistem pengendalian didalam organisasi (Bastian : 2002) yaitu:

a) Pendekatan dari sudut pengolahan transaksi organisasi.

Pengolahan transaksi bersumber dari data yang diproses untuk menghasilkan informasi.Pendekatan ini berhubungan dengan kegiatan pengendalian akuntansi berupa pengendalian yang berhubungan dengan transaksi atau aplikasinya dan pengendalian yang bersifat umum.

b) Pendekatan dari sudut aspek manajerial dan pengambilan keputusan

Aspek manajerial dan pengambilan keputusan hendaknya didukung oleh sistem informasi yang akan menciptakan sistem pengendalian. Sistem informasi ini disebut sistem pengendalian manajemn yang meliputi kegiatan membandingkan realisasi dengan kriteria perencanaan sebagai landasan pengambil tindakan koreksi.

\section{A. Hipotesis}

H1 : Akuntabilitas berpengaruh signifikan negatif terhadap potensi kecurangan dana desa.

H2 : Kesesuaian kompensasi berpengaruh signifikan negatif terhadap potensi kecurangan dana desa.

H3 : Pengendalian intern berpengaruh signifikan positif terhadap potensi kecurangan dana desa.

\section{METODE PENELITIAN}

Jenis penelitian ini merupakan penelitian kausitas, yaitu untuk mengetahui hubungan dan pengaruh antara variable dependen dengan independen. Populasi yang digunakan dalam penelitian ini adalah 79 desa di Kabupaten Lima Puluh Kota. Metode yang digunakan dalam penelitian ini adalah metode total sampling. Jenis data yang digunakan adalah sata subjek, sedangkan sumber data yang dugunakan adalah data primer. Data tersebut diperoleh secara langsung dengan menggunakan kuesionenr dari subjek penelitian yaitu kepala desa, sekretaris desa dan bendahara desa. Metode pengumpulan data untuk penelitian ini dengan cara menyebar kuesioner kepada kepala desa, sekretaris desa dan bendahara desa yang ada di Kabupaten Lima Puluh Kota. 


\section{HASIL DAN PEMBAHASAN}

\section{Demografi Responden (Gambaran Umum Responden)}

Tabel 1

\begin{tabular}{|l|c|}
\hline \multicolumn{2}{|c|}{ Penyebaran dan Pengembalian kuesioner } \\
\hline Keterangan & Jumlah \\
\hline Jumlah Kuesioner yang disebar & 237 \\
\hline Jumlah kuesioner yang kembali & 159 \\
\hline Respon Rate & $\mathbf{6 7 , 0 8 \%}$ \\
\hline
\end{tabular}

Berdasarkan tabel 1 diatas, kuesioner yang dikembalikan berjumlah 159, yaitu dengan persentase pengembalian kuesioner adalah sebesar $67,08 \%$. Hal ini menjelaskan bahwa kuesioner yang disebarkan cukup tinggi tingkat pengembaliannya.

\section{A. Uji Kualitas Data}

\section{Uji Validitas}

Tabel 2

Uji Validitas

\begin{tabular}{|l|c|}
\hline \multicolumn{1}{|c|}{ Instrumen Variabel } & $\begin{array}{c}\text { Nilai Corrected Item-Total } \\
\text { Correlation terkecil }\end{array}$ \\
\hline Potensi Kecurangan (Y) & 0.215 \\
\hline Akuntabilitas (X1) & 0.379 \\
\hline Kesesuaian Kompensasi (X2) & 0.433 \\
\hline Pengendalian Intern (X3) & 0.594 \\
\hline
\end{tabular}

Sumber: Data Primer yang sudah diolah

Berdasarkan tabel 2 uji validitas di atas dapat dilihat nilai terkecil dariCorrected Item-Total Correlation untuk masing-masing instrumen yaitu lebih dari 0,159. Untuk instrumen Akuntabilitas $\left(\mathrm{X}_{1}\right)$ diketahui nilai Corrected Item-Total Correlation sebesar 0,379, Kesesuaian Kompensasi $\left(\mathrm{X}_{2}\right)$ adalah sebesar 0,433, Pengendalian Intern $\left(\mathrm{X}_{3}\right)$ adalah sebesar 0.594 dan untuk potensi kecurangan (Y) sebesar 0,215. Jadi dapat dikatakan bahwa semua item pernyataan variabel $\mathrm{Y}, \mathrm{X}_{1}, \mathrm{X}_{2}$, dan $\mathrm{X}_{3}$ adalah valid.

\section{Uji Reliabilitas}

Tabel 3

Uji Reliabilitas

\begin{tabular}{|l|c|c|}
\hline \multicolumn{1}{|c|}{ Instrumen Variabel } & $\begin{array}{c}\text { Nilai } \\
\text { Cronbach } \\
\text { Alpha }\end{array}$ & Ket \\
\hline Potensi Kecurangan (Y) & 0.640 & Reliabel \\
\hline Akuntabilitas (X1) & 0.810 & Reliabel \\
\hline Kesesuaian Kompensasi (X2) & 0.605 & Reliabel \\
\hline Pengendalian Intern (X3) & 0.659 & Reliabel \\
\hline
\end{tabular}

Sumber: Data Primer yang sudah diolah

Hasil tersebut menunjukkan bahwa semua variabel mempunyai Cronbach Alpha yang cukup besar yaitu di atas 0,60 sehingga dapat dikatakan semua konsep pengukur masing-masing 
variabel dari kuesioner adalah reliabel sehingga untukselanjutnya item-item pada masing-masing konsep variabel tersebut layakdigunakan sebagai alat ukur.

\section{Uji Normalitas}

Tabel 4

Uji Normalitas

One-Sample Kolmogorov-Smirnov Test

\begin{tabular}{|ll|r|}
\hline & & $\begin{array}{c}\text { Unstandardized } \\
\text { Residual }\end{array}$ \\
\hline $\mathrm{N}$ & & 159 \\
Normal Parameters & & .0000000 \\
& Mean & 2.15756105 \\
Most Extreme Differences & Std. Deviation & .070 \\
& Absolute & .049 \\
& Positive & -.070 \\
Kolmogorov-Smirnov Z & Negative & .883 \\
Asymp. Sig. (2-tailed) & & .417 \\
\hline a. Test distribution is Normal. &
\end{tabular}

Berdasarkan hasil uji normalitas diatas terlihat bahwa hasil uji normalitas menunjukkan level signifikasi lebih besar dari $\alpha(\alpha=0,05)$ yaitu $0,417>0,05$ yang berarti bahwa data terdistribusi secara normal.

\section{Uji Heteroskedastisitas}

Tabel 5

Uji Heteroskedastisitas

Coefficients $^{\mathrm{a}}$

\begin{tabular}{|c|c|c|c|c|c|}
\hline \multirow[b]{2}{*}{ Model } & \multicolumn{2}{|c|}{$\begin{array}{c}\text { Unstandardized } \\
\text { Coefficients }\end{array}$} & \multirow{2}{*}{\begin{tabular}{|c}
$\begin{array}{c}\text { Standardiz } \\
\text { ed } \\
\text { Coefficient } \\
\text { s }\end{array}$ \\
Beta
\end{tabular}} & \multirow[b]{2}{*}{$\mathrm{t}$} & \multirow[b]{2}{*}{ Sig. } \\
\hline & B & $\begin{array}{l}\text { Std. } \\
\text { Error }\end{array}$ & & & \\
\hline $1 \quad$ (Constant) & 3.553 & 2.100 & & 1.692 & .093 \\
\hline Akuntabilitas & .008 & .041 & .023 & .187 & .852 \\
\hline $\begin{array}{l}\text { kesesuaian } \\
\text { kompensasi }\end{array}$ & -.011 & .082 & -.011 & -.131 & .896 \\
\hline $\begin{array}{l}\text { pengendalian } \\
\text { intern }\end{array}$ & -.041 & .052 & -.096 & -.783 & .435 \\
\hline
\end{tabular}

a. Dependent Variable: RES_2

Sumber: Data Primer yang sudah diolah

Berdasarkan table1 5 dapat dilihat bahwa hasil perhitungan masing-masing variabel menunjukkan bahwa level sig $>0,05$ yaitu 0,852>0,05 untuk akuntabilitas, 0,896 > 0,05 untu 
variable kesesuaian kompensasi dan 0,435>0,05 untuk variabel pengendalian intern. Artinya tidak terdapat gejala heteroskedastisitas dalam penelitian ini.

\section{Deskriptif Hasil Penelitian}

Deskripsi hasil penelitian merupakan deskripsi dari hasil penelitian tentang akuntabilitas, kesesuaian kompensasi dan pengendalian intern terhadap potensi kecurangan dana desa di Kabupaten Lima Puluh Kota Variabel-Variabel tersebut dapat dikategorikan berdasarkan :

\section{a) Distribusi Variabel Potensi Kecurangan (Y)}

Distribusi frekuensi skor variabel potensi kecurangan terdapat 12 buah pernyataan. Data yang diperoleh dari distribusi variabel potensi kecurangan adalah sebagai berikut:

Tabel 6

\section{Distribusi Frekuensi Variabel Potensi Kecurangan}

\begin{tabular}{|c|c|c|c|c|}
\hline No & Pernyataan & $\begin{array}{l}\text { Rata- } \\
\text { Rata }\end{array}$ & $\begin{array}{c}\mathrm{TCR} \\
(\%)\end{array}$ & Ket \\
\hline 1. & $\begin{array}{l}\text { Perangkat desa mencatat tanggal } \\
\text { transaksi tidak sesuai dengan waktu } \\
\text { transaksi yang sebenarnya }\end{array}$ & 4,62 & 92 & $\begin{array}{l}\text { Sangat } \\
\text { Baik }\end{array}$ \\
\hline 2. & $\begin{array}{l}\text { Kepala desa seharusnya berusaha untuk tidak } \\
\text { menerima berbagai pendapat fiktif yang ada di } \\
\text { kantor desa }\end{array}$ & 4,52 & 90 & $\begin{array}{l}\text { Sangat } \\
\text { Baik }\end{array}$ \\
\hline 3. & $\begin{array}{l}\text { Kepala desa tidak memperkecil biaya-biaya } \\
\text { yang tercatatat di dalam pembukuan dana desa } \\
\text { agar laporan dana desa terlihat lebih baik. }\end{array}$ & 4,73 & 95 & $\begin{array}{l}\text { Sangat } \\
\text { Baik }\end{array}$ \\
\hline 4. & $\begin{array}{l}\text { Perangkat desa melaporkan pengungkapan } \\
\text { atas laporan keuangan yang memadai dan } \\
\text { tidak ada yang ditutup-tutupi }\end{array}$ & 4,72 & 94 & $\begin{array}{l}\text { Sangat } \\
\text { Baik }\end{array}$ \\
\hline 5. & $\begin{array}{l}\text { Perangkat desa menilai kembali atas aset yang } \\
\text { sesuai dengan ketentuan yang berlaku }\end{array}$ & 4,65 & 93 & $\begin{array}{c}\text { Sangat } \\
\text { Baik }\end{array}$ \\
\hline 6. & $\begin{array}{l}\text { Dana desa harus dikelola oleh orang yang } \\
\text { bertanggungjawab dan jujur }\end{array}$ & 4,68 & 94 & $\begin{array}{l}\text { Sangat } \\
\text { Baik }\end{array}$ \\
\hline 7. & $\begin{array}{l}\text { Di desa tidak terjadi pengeluaran yang ilegal } \\
\text { atau tidak sesuai dengan prosedur yang telah } \\
\text { ditetapkan }\end{array}$ & 4,52 & 90 & $\begin{array}{l}\text { Sangat } \\
\text { Baik }\end{array}$ \\
\hline 8. & $\begin{array}{l}\text { Perangkat desa tidak menggunakan aset untuk } \\
\text { kepentingan pribadi }\end{array}$ & 4,67 & 93 & $\begin{array}{l}\text { Sangat } \\
\text { Baik }\end{array}$ \\
\hline 9. & $\begin{array}{l}\text { Kepala desa membuat perencanaan yang } \\
\text { mengutamakan kepentingan pribadi }\end{array}$ & 4,64 & 93 & $\begin{array}{c}\text { Sangat } \\
\text { Baik }\end{array}$ \\
\hline 10. & $\begin{array}{l}\text { Desa tidak menerima suap dalam bentuk } \\
\text { apapun }\end{array}$ & 4,63 & 93 & $\begin{array}{c}\text { Sangat } \\
\text { Baik }\end{array}$ \\
\hline 11. & $\begin{array}{l}\text { Kepala desa tidak mmberikan hadiah kpd } \\
\text { rekan bisnisnya setelah membuat sebuah } \\
\text { kesepakatan tertentu }\end{array}$ & 4,68 & 94 & $\begin{array}{l}\text { Sangat } \\
\text { Baik }\end{array}$ \\
\hline \multirow[t]{2}{*}{12.} & $\begin{array}{l}\text { Di desa tidak pernah ditemukan praktik } \\
\text { pemerasan yang dilakukan terhadap } \\
\text { karyawan atau masyarakat }\end{array}$ & 4,49 & 90 & $\begin{array}{l}\text { Sangat } \\
\text { Baik }\end{array}$ \\
\hline & Rata-Rata & 4,62 & 92,5 & $\begin{array}{l}\text { Sangat } \\
\text { Baik }\end{array}$ \\
\hline
\end{tabular}

Sumber: Data Primer yang sudah diolah

Berdasarkan tabel distribusi frekuensi variabel tersebut dapat dilihat bahwa tingkat capaian responden tertinggi berada pada pernyataan no.3, dengan tingkat capaian responden $95 \%$ 
kategori sangat baik,yaitu kepala desa tidak memperkecil biaya-biaya yang tercatatat di dalam pembukuan dana desa agar laporan dana desa terlihat lebih baik.,sedangkan untuk tingkat capaian responden terendah berada pada pernyataan no.12 yaitu sebesar $90 \%$.Rata-rata tingkat capaian responden pada variabel potensi kecurangan adalah sebesar 92,5\%, dengan demikian rerata tingkat capaian responden variabel potensi kecurangan dikategorikan sangat baik.

b) Distribusi Variabel Akuntabilitas (X1)

Distribusi frekuensi skor variabel akuntabilitas terdapat 13 buah pernyataan. Data yang diperoleh dari distribusi variabel budaya organisasi adalah sebagai berikut:

Tabel 7

Distribusi Frekuensi Variabel Akuntabilitas

\begin{tabular}{|c|c|c|c|c|}
\hline No & Pernyataan & $\begin{array}{l}\text { Rata- } \\
\text { Rata }\end{array}$ & $\begin{array}{l}\text { TCR } \\
(\%)\end{array}$ & Ket \\
\hline 1. & $\begin{array}{l}\text { Pelaksaan kebijakan dipertanggungjawabkan } \\
\text { perangkat desa kepada pemerintah daerah dan } \\
\text { masyarakat }\end{array}$ & 4,82 & 96 & $\begin{array}{c}\text { Sangat } \\
\text { baik }\end{array}$ \\
\hline 2. & $\begin{array}{l}\text { Kebijakan yang diambil sudah berdasarkan } \\
\text { kebutuhan masyarakat }\end{array}$ & 4,72 & 94 & $\begin{array}{l}\text { Sangat } \\
\text { baik }\end{array}$ \\
\hline 3. & $\begin{array}{l}\text { Perangkat desa memberikan laporan } \\
\text { akuntabilitas kinerja tahunan sebagai bentuk } \\
\text { pertanggungjawaban pelaksanaan anggaran } \\
\text { kepada pemerintah daerah dan masyarakat }\end{array}$ & 4,70 & 94 & $\begin{array}{l}\text { Sangat } \\
\text { baik }\end{array}$ \\
\hline 4. & $\begin{array}{l}\text { Anggaran yang dirancang dan ditetapkan oleh } \\
\text { perangkat desa bersama pemerintah daerah } \\
\text { sesuai dengan realisasinya bagi kepentingan } \\
\text { publik atau masyarakat }\end{array}$ & 4,69 & 94 & $\begin{array}{l}\text { Sangat } \\
\text { baik }\end{array}$ \\
\hline 5. & $\begin{array}{l}\text { Program-program dana desa dirancang dengan } \\
\text { mempertimbangkan efisiensi bahwa dana desa } \\
\text { menghasilkan output yang maksimal }\end{array}$ & 4,69 & 94 & $\begin{array}{l}\text { Sangat } \\
\text { baik }\end{array}$ \\
\hline 6. & $\begin{array}{l}\text { Program-program dana desa dirancang dengan } \\
\text { mempertimbangkan prinsip efektivitas bahwa } \\
\text { penggunaan anggaran mencapai target dan } \\
\text { tujuan kepentingan publik atau masyarakat }\end{array}$ & 4,67 & 93 & $\begin{array}{l}\text { Sangat } \\
\text { baik }\end{array}$ \\
\hline 7. & $\begin{array}{l}\text { Pelaksanaan program-program dana desa } \\
\text { benar benar dirasakan manfaatnya oleh } \\
\text { masyarakat }\end{array}$ & 4,62 & 92 & $\begin{array}{l}\text { Sangat } \\
\text { baik }\end{array}$ \\
\hline 8. & $\begin{array}{l}\text { Pengalokasian dana desa mengikuti proses- } \\
\text { proses dari prosedur yang berlaku }\end{array}$ & 4,53 & 91 & $\begin{array}{l}\text { Sangat } \\
\text { baik }\end{array}$ \\
\hline 9. & $\begin{array}{l}\text { Penggunaan dana desa didasrkan atas } \\
\text { peraturan perundang-undangan serta petunjuk } \\
\text { teknis dan pelaksanaanya }\end{array}$ & 4,64 & 93 & $\begin{array}{l}\text { Sangat } \\
\text { baik }\end{array}$ \\
\hline 10 . & $\begin{array}{l}\text { Perangkat desa mampu menyusun semua } \\
\text { laporan keuangan untuk dana desa (Laporan } \\
\text { realisasi anggaran, neraca dan catatan atas } \\
\text { laporan keuangan) }\end{array}$ & 4,64 & 93 & $\begin{array}{l}\text { Sangat } \\
\text { baik }\end{array}$ \\
\hline 11. & $\begin{array}{l}\text { Perangkat desa jujur dalam } \\
\text { mempertanggungjawabkan setiap laporannya }\end{array}$ & 4,62 & 92 & $\begin{array}{c}\text { Sangat } \\
\text { baik }\end{array}$ \\
\hline 12. & $\begin{array}{l}\text { Adanya sanksi hukum yang tegas bagi aparat } \\
\text { dan instasinya dalam penyalahgunaan } \\
\text { wewenang }\end{array}$ & 4,65 & 93 & $\begin{array}{c}\text { Sangat } \\
\text { baik }\end{array}$ \\
\hline
\end{tabular}




\begin{tabular}{|l|l|c|l|c|}
\hline 13. & $\begin{array}{l}\text { Penggunaan dana desa didasrkan atas hukum } \\
\text { dan peraturan yang berlaku }\end{array}$ & 4,69 & 94 & $\begin{array}{c}\text { Sangat } \\
\text { baik }\end{array}$ \\
\hline & Rata-Rata & $\mathbf{4 , 6 6}$ & $\mathbf{9 3 , 3}$ & $\begin{array}{c}\text { Sangat } \\
\text { baik }\end{array}$ \\
\hline
\end{tabular}

Sumber: Data Primer yang sudah diolah

Berdasarkan tabel distribusi frekuensi variabel tersebut dapat dilihat bahwa tingkat capaian responden tertinggi berada pada pernyataan no.1 dengantingkat capaian responden $96 \%$ kategori sangat baik,yaituPelaksaan kebijakan dipertanggungjawabkan perangkat desa kepada pemerintah daerah dan masyarakat. Pada pernyataan no.2dengan tingkat capaian responden sebesar 94\%,Kebijakan yang diambil sudah berdasarkan kebutuhan masyarakat,untuk rata-rata tingkat capaian responden pada variabel akuntabilitasadalah sebesar 93,3\%, dengan demikian dapat dikategori kan sangat baik secara keseluruhan.

\section{c) Distribusi Variabel Kesesuaian Kompensasi (X2)}

Distribusi frekuensi skor variabel kesesuaian kompensasi terdapat 3buah pernyataan.Data yang diperoleh dari distribusi variabel kesesuaian kompensasi adalah sebagai berikut:

\section{Tabel 8}

Distribusi Frekuensi Variabel Kesesuaian Kompensasi

\begin{tabular}{|l|l|l|l|c|}
\hline No & \multicolumn{1}{|c|}{ Pernyataan } & $\begin{array}{c}\text { Rata } \\
- \\
\text { Rata }\end{array}$ & $\begin{array}{c}\text { TCR } \\
(\%)\end{array}$ & Ket \\
\hline 1 & $\begin{array}{l}\text { Kompensasi keuangan yang diberikan } \\
\text { diukur sesuai dengan prestasi pekerjaan } \\
\text { yang dilakukan oleh karyawan }\end{array}$ & 4,62 & 92 & $\begin{array}{c}\text { Sangat } \\
\text { Baik }\end{array}$ \\
\hline 2 & $\begin{array}{l}\text { Kepala desa menciptakan kondisi } \\
\text { sehingga diakui bahwa semua } \\
\text { karyawan memang menguasai } \\
\text { pekerjaan yang menjadi tanggungj } \\
\text { awab masing-masing }\end{array}$ & 4,53 & 91 & $\begin{array}{c}\text { Sangat } \\
\text { Baik }\end{array}$ \\
\hline 3 & $\begin{array}{l}\text { Promosi di kantor desa dilakukan } \\
\text { setiap tahunnya }\end{array}$ & 4,62 & 92 & $\begin{array}{c}\text { Sangat } \\
\text { Baik }\end{array}$ \\
\hline & $\begin{array}{l}\text { Rata-Rata } \\
\text { Baik }\end{array}$ \\
\hline
\end{tabular}

Sumber: Data Primer yang sudah diolah

Berdasarkan tabel distribusi frekuensi variabel tersebut dapat dilihat bahwa tingkat capaian responden tertinggi berada pada pernyataan no.1dengan tingkat capaian responden $92 \%$ kategori sangat baik,yaitu Kompensasi keuangan yang diberikan diukur sesuai dengan prestasi pekerjaan yang dilakukan oleh karyawan,sedangkan untuk tingkat capaian responden terendah berada pada pernyataan no. 2 dengan tingkat capaian responden $91 \%$, untuk rata-rata tingkat capaian responden pada variabel kesesuaian kompensasi adalah sebesar 91,78\% dengan kategori sangat baik.

\section{d) Distribusi Variabel Pemgendalian Intern (X3)}

Distribusi frekuensi skor variabel pengendalian intern terdapat 11 buah pernyataan. Data yang diperoleh dari distribusi variabel pengendalian intern adalah sebagai berikut: 
Tabel 9

Distribusi Frekuensi Variabel Pengendalian Interm

\begin{tabular}{|c|c|c|c|c|}
\hline No & Pernyataan & $\begin{array}{l}\text { Rata- } \\
\text { Rata }\end{array}$ & $\begin{array}{l}\text { TCR } \\
(\%)\end{array}$ & Ket \\
\hline 1. & $\begin{array}{l}\text { Kepala desa memberikan contoh perilaku } \\
\text { etis dan beretika kepada seluruh staff dan } \\
\text { masyarakatnya }\end{array}$ & 4,63 & 93 & $\begin{array}{c}\text { Sangat } \\
\text { Baik }\end{array}$ \\
\hline 2. & $\begin{array}{l}\text { Kepala desa tidak menetapkan tingkat } \\
\text { kompetensi kepada bawahannya }\end{array}$ & 4,69 & 94 & $\begin{array}{c}\text { Sangat } \\
\text { Baik }\end{array}$ \\
\hline 3. & $\begin{array}{l}\text { Kantor desa mempunyai tim khusus yang } \\
\text { berpengalaman dan independen untuk } \\
\text { pemeriksaan laporan keuangan desa }\end{array}$ & 4,64 & 93 & $\begin{array}{c}\text { Sangat } \\
\text { Baik }\end{array}$ \\
\hline 4. & $\begin{array}{l}\text { Kantor desa tidak memiliki kebijakan } \\
\text { tertulis dan indikator kerja }\end{array}$ & 4,64 & 93 & $\begin{array}{c}\text { Sangat } \\
\text { Baik }\end{array}$ \\
\hline 5. & $\begin{array}{l}\text { Kantor desa memiliki struktur organisasi } \\
\text { yang tepat sesuai dengan kebutuhan }\end{array}$ & 4,45 & 89 & $\begin{array}{c}\text { Sangat } \\
\text { Baik }\end{array}$ \\
\hline 6. & $\begin{array}{l}\text { Kantor desa tidak memiliki kebijakan } \\
\text { pembaruan tugas dan tanggungjawab yang } \\
\text { jelas }\end{array}$ & 4,52 & 90 & $\begin{array}{c}\text { Sangat } \\
\text { Baik }\end{array}$ \\
\hline 7. & $\begin{array}{l}\text { Kantor desa menetapkan kebijakan tertulis } \\
\text { tentang perekrutan, orientasi, pelaihan, } \\
\text { motivasi, promosi, kompetensi dan } \\
\text { perlindungan bagi staff nya }\end{array}$ & 4,48 & 90 & $\begin{array}{c}\text { Sangat } \\
\text { Baik }\end{array}$ \\
\hline 8. & $\begin{array}{l}\text { Kantor desa menilai tingkat resiko terkait } \\
\text { denga produk dan transaksi-transaksi } \\
\text { penggunaan dana desa }\end{array}$ & 4,62 & 92 & $\begin{array}{c}\text { Sangat } \\
\text { Baik }\end{array}$ \\
\hline 9. & $\begin{array}{l}\text { Kantor desa tidak menetapkan pengukuran } \\
\text { resiko }\end{array}$ & 4,64 & 93 & $\begin{array}{c}\text { Sangat } \\
\text { Baik }\end{array}$ \\
\hline 10 & $\begin{array}{l}\text { Kantor desa tidak menentukan batas dan } \\
\text { toleransi resiko }\end{array}$ & 4,62 & 92 & $\begin{array}{c}\text { Sangat } \\
\text { Baik }\end{array}$ \\
\hline \multirow[t]{2}{*}{11} & $\begin{array}{l}\text { Kantor desa menetapkan adanya } \\
\text { pengendalian intern }\end{array}$ & 4,69 & 94 & $\begin{array}{c}\text { Sangat } \\
\text { Baik }\end{array}$ \\
\hline & Rata-Rata & 4,59 & 91,8 & $\begin{array}{c}\text { Sangat } \\
\text { Baik }\end{array}$ \\
\hline
\end{tabular}

Sumber: Data Primer yang sudah diolah

Berdasarkan tabel distribusi frekuensi variabel tersebut dapat dilihat bahwa tingkat capaian responden tertinggi berada pada pernyataan no.2 dengan tingkat capaian responden $94 \%$ kategori sangat baik,yaitu Kepala desa tidak menetapkan tingkat kompetensi kepada bawahannya,sedangkan untuk tingkat capaian responden terendah berada pada pernyataan no.5 dengan tingkat capaian responden $89 \%$, untuk rata-rata tingkat capaian responden pada variabel kesesuaian kompensasi adalah sebesar 91,8\% dengan kategori sangat baik. 


\section{B. Hasil Analisis Regresi}

Tabel 10

Uji Regresi Berganda

Coefficients $^{\mathrm{a}}$

\begin{tabular}{|c|c|c|c|c|c|c|}
\hline \multirow{2}{*}{\multicolumn{2}{|c|}{ Model }} & \multicolumn{2}{|c|}{$\begin{array}{l}\text { Unstandardize } \\
\text { d Coefficients }\end{array}$} & \multirow{2}{*}{$\begin{array}{c}\text { Standar } \\
\text { dized } \\
\text { Coeffic } \\
\text { ients } \\
\text { Beta } \\
\end{array}$} & \multirow[b]{2}{*}{$\mathrm{T}$} & \multirow[b]{2}{*}{ Sig. } \\
\hline & & B & $\begin{array}{l}\text { Std. } \\
\text { Erro } \\
\text { r }\end{array}$ & & & \\
\hline \multirow[t]{4}{*}{1} & (Constant) & $\begin{array}{r}27.9 \\
60\end{array}$ & $\begin{array}{r}3.82 \\
9\end{array}$ & & $\begin{array}{r}7.30 \\
2\end{array}$ & .000 \\
\hline & akuntabilitas & $\begin{array}{r}- \\
.003\end{array}$ & .075 & -.004 &. & .966 \\
\hline & $\begin{array}{l}\text { kesesuaian } \\
\text { kompensasi }\end{array}$ & $\begin{array}{r}- \\
.049\end{array}$ & .150 & -.022 & .329 & .742 \\
\hline & pengendalian intern & .562 & .096 & .586 & $\begin{array}{r}5.87 \\
7\end{array}$ & .000 \\
\hline
\end{tabular}

a. Dependent Variable: potensi kecurangan

$\backslash$ Analisis regresi berganda digunakan untuk mengetahui ada tidaknya pengaruh variable bebas terhadap variabel terikat. Berdasarkan tabel 10 dapat dianalisis model estimasi sebagai berikut:

$$
Y=27.960+-0,003 X 1+-0,049 X 2+0.562 X 3+e
$$

Keterangan:

$\mathrm{Y}=$ Potensi kecurangan

$\mathrm{X} 1=$ Akuntabilitas

$\mathrm{X} 2=$ Kesesuaian Kompensasi

$\mathrm{X} 3=$ Pengendalian Intern

\section{Uji Model}

\section{Uji Koefisien Determinasi $\left(\mathbf{R}^{2}\right)$}

Berdasarkan perhitungan $\mathrm{R}^{2}$ menggunakan SPSS diperoleh nilai Adjusted RSquare sebesar 0.324. Hal ini menunjukkan bahwa variabel akuntabilitas, kesesuaian kompensasi dan pengendalian intern memilki kontribusi dalam menjelaskan variabel potensi kecurangan sebesar $32.4 \%$, sedangkan $67.6 \%$ lainnya ditentukan oleh faktor lain di luar model yang tidak terdeteksi dalam penelitian ini

2. Uji F (F-Test)

Hasil pengolahan statistik analisis regresi menunjukkan nilai $\mathrm{F}=26.276$ dan signifikan pada

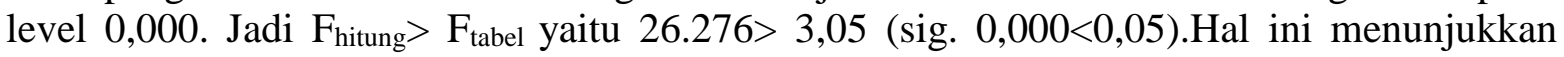
bahwa model regresi dapat digunakan untuk menguji pengaruh variabel independen terhadap variabel dependen, dengan demikian dapat disimpulkan bahwa akuntabilitas, kesesuaian kompensasi dan pengendalian intern secara bersama-sama atau secara simultan berpengaruh signifikan terhadap potensi kecurangan 


\section{Uji Hipotesis}

Uji t statistik (t-test) bertujuan untuk mengetahui hubungan yang signifikan dari masing-masing variabel bebas terhadap variabel terikatnya. Pengujian hipotesis secara parsial dilakukan dengan cara membandingkan nilai thitung dengan nilai tabel. Nilai tabel adalah $a=0,05$ dengan derjat bebas $(\mathrm{db})=\mathrm{n}-\mathrm{k}-1=159-2-1=156$ adalah 1.654 , berdasarkan hasil analisis pada tabel 17 maka dapat diketahui pengaruh variabel independen secara parsial terhadap variabel dependen adalah sebagai berikut:

\section{Hipotes Pertama (H1)}

Pengujian hipotesis dilakukan dengan membandingkan thitung dengan nilai tabel. Hipotesis diterima jika $t_{\text {hitung }}>t_{\text {tabel }}$ atau nilai sig $<0,05$. Nilai ttabel pada 0,05 adalah 1.654 , untuk variabel akuntabilitas $\left(\mathrm{X}_{1}\right)$ nilai thitung adalah $-0,043$ dan nilai sig adalah 0,966 ,dengan demikian dapat dikatakan bahwa $t_{\text {hitung }}<t_{\text {tabel }}$ yaitu $-0,043<1.654$ atau nilai signifikasi $0,966>0,05$. Nilai koefisien $\beta$ dari variabel $X_{1}$ bernilai negatif yaitu-0,003.Hal ini menunjukkan bahwa akuntabilitas $\left(\mathrm{X}_{1}\right)$ berpengaruh signifikan negatif terhadap pencegahan potensi kecurangan,dengan demikian dapat dikatakan bahwa hipotesis pertama $\left(\mathrm{H}_{1}\right)$ ditolak.

\section{Hipotesis Kedua (H2)}

Pengujian hipotesis dilakukan dengan membandingkan thitung dengan nilai $t_{\text {tabel }}$. Hipotesis diterima jika $t_{\text {hitung }}>t_{t a b e l}$ atau nilai sig $<0,05$. Nilai $t_{\text {abel }}$ pada 0,05 adalah1.654, untuk variabel kesesuaian kompensasi $\left(\mathrm{X}_{2}\right)$ nilai thitung adalah $-0,329$ dan nilai sig adalah 0.742 , dengan demikian dapat dikatakan bahwa $t_{\text {hitung }}<\mathrm{t}_{\text {tabel }}$ yaitu $-0.329<1.654$ atau nilai signifikasi $0.742>0,05$. Nilai koefisien $\beta$ dari variabel $X_{2}$ bernilai negatif yaitu-0.049. Hal ini menunjukkan bahwa kesesuaian kompensasi $\left(\mathrm{X}_{2}\right)$ berpengaruh signifikan negatif terhadap potensi kecurangan,dengan demikian dapat dikatakan bahwa hipotesis kedua $\left(\mathrm{H}_{2}\right)$ ditolak.

\section{Hipotesis Ketiga (H3)}

Pengujian hipotesis dilakukan dengan membandingkan thitung dengan nilai $t_{t a b e l}$. Hipotesis diterima jika $t_{\text {hitung }}>t_{\text {tabel }}$ atau nilai sig $<0,05$. Nilai $t_{\text {abel }}$ pada 0,05 adalah1.654, untuk variabel pengendalian intern $\left(\mathrm{X}_{3}\right)$ nilai $\mathrm{t}_{\text {hitung }}$ adalah 5,877dan nilai sig adalah 0.000 ,dengan demikian dapat dikatakan bahwa $t_{\text {hitung }}>t_{\text {tabel }}$ yaitu 5,877>1.654atau nilai signifikasi $0.000<0,05$. Nilai koefisien $\beta$ dari variabel $X_{3}$ bernilai positif yaitu0.562. Hal ini menunjukkan bahwa pengendalian intern $\left(\mathrm{X}_{3}\right)$ berpengaruh signifikan positif terhadap potensi kecurangan,dengan demikian dapat dikatakan bahwa hipotesis ketiga $\left(\mathrm{H}_{3}\right)$ diterima.

\section{Pembahasan}

Pada bagian ini dilakukan pembahasan berkaitan dengan hasil penelitian yang dipaparkan sebelumnya, adapun hasil pembahasannya adalah :

\section{Pengaruh Akuntabilitas terhadap Potensi Kecurangan}

Hasil pengujian hipotesisdalam penelitian ini memberikan bukti bahwa variabel akuntabilitas berpengaruh signifikan negatif terhadap potensi kecurangan, hal ini menunjukkan bahwa staff nagari belum mempunyai akuntabilitas tinggi terhadap dana desa sehingga kemungkinan akan terjadi potensi kecurangan terhadapdana desa.

Akuntabilitas mengandung arti pertanggungjawaban, baik oleh orang maupun badanbadan yang terpilih, atas pilihan-pilihan dan tindakan tindakannya (Budi Mulyana, 2006 dalam 
Setiawan, 2012). Dalam hal ini perangkat desa harus terbuka dan responbilitas terhadap proses pencatatan akuntansi serta manajemen keuangan sehingga besar harapan perangkat desa dapat mengelola keuangan dan melaporkannya secara transparan, akuntabel dan transpatif. Hal ini dapat dilakukan untuk meminimalkan potensi kecurangan dalam pengelolaan keuangan desa.

Penelitian ini sejalan dengan penelitian yang dilakukan oleh Oktaviani (2017) menjelaskan bahwa akuntabilitas berpengaruh negatif dan signifikan terhadap potensi kecurangandalam pengelolaan keuangan desa. Makin rendah akuntabilitas maka akan terjadi potensi kecurangan terhadap dana desa.

\section{Pengaruh Kesesuaian Kompensasi terhadap Potensi Kecurangan}

Hasil pengujian hipotesis dalam penelitian inimemberikan bukti bahwa kesesuaian kompensasi berpengaruh signifikan negatif terhadap potensi kecurangan, hal ini menunjukkan staff nagari belum merasa puas dengan kompensasi yang diterima sehingga kemungkinan menimbulkan adanya potensi kecurangan terhadap dana desa dapat dihindari.

Jensen and Meckling (1976) dalam penelitian Thoyibatun (2009) menjelaskan bahwa prinsipal dapat memecahkan permasalahan antara principal dan agen dengan memberi kompensasi yang sesuai kepada agen, dengan mengeluarkan biaya monitoring. Dengan kompensasi yang sesuai, perilaku kecurangan akuntansi dapat berkurang. Penelitian ini sama dengan penelitian yang dilakukan oleh Sanuari (2014) menjelaskan bahwa kesesuaian kompensasi berpengaruh negatif terhadap kecendrungan kecurangan akuntansi.Dimana makin kecil kompensasi yang diterima maka mereka akan cendrung untuk melakukan kecurangan terhadap dana desa.

\section{Pengaruh Pengendalian Intern terhadap Potensi Kecurangan}

Hasil pengujian hipotesis dalam penelitian inimemberikan bukti bahwa pengendalian intern berpengaruh signifikanpositif terhadap potensi kecurangan, hal ini bukti bahwa pimpinan telah menciptakan pengendalian yang baik terhadap dana desa sehingga tidak terjadi lagi potensi kecurangan terhadap dana desa.

Wilopo (2006), menyatakan bahwa pengendalian internal yang efektif dapat mencegah kecenderungan kecurangan akuntansi. Boyton (2000:372) semua perusahaan publik harus memelihara pengendalian internal yang akan menyediakan keyakinan yang memadai bahwa pelaporan keuangan yang curang akan dicegah atau dideteksi dari awal. Menurut Agoes (2009:229) kecurangan dapat dicegah dengan cara membangun struktur pengendalian yang baik, pilih karyawan yang jujur dengan seleksi pegawai secara ketat, meningkatkan keandalan departemen audit internal, memberikan imbalan yang memadai untuk seluruh pegawai, lakukan rotation of duties dan karyawan wajib menggunakan hak cuti, pembinaan rohani, memberikan penghargaan kepada mereka yang berprestasi, menimbulkan iklim keterbukaan dalam perusahaan dan membuat kebijakan tertulis mengenai fair dealing.

Penelitian ini tidak sama dengan penelitian yang dilakukan oleh Sanuari (2014) menjelaskan bahwa pengendalian intern berpengaruh negatif terhadap kecendrungan kecurangan akuntansi.

\section{SIMPULAN, KETERBATASAN DAN SARAN \\ Simpulan}

Berdasarkan hasil penelitian dan pembahasan yang telah dipaparkan maka dapat ditarik kesimpulan sebagai berikut: (1) Akuntabilitas berpengaruh signifikan negative terhadap potensi 
kecurangan dana desa (2) Kesesuaian kompensasi berpengaruh signifikan negative terhadap potensi kecurangan dana desa (3) Pengendalian intern berpengaruh signifikan negative terhadap potensi kecurangan dana desa

\section{Keterbatasan}

Seperti kebanyakan penelitian lainnya, penelitian ini memiliki keterbatasan, yaitu: penelitian ini merupakan metode survei menggunakan kuesioner. Data penelitian yang berasal dari responden yang disampaikan secara tertulis mungkin akan mempengaruhi hasil penelitian,karena persepsi responden yang disampaikan belum tentu mencerminkan keadaan yang sebenarnya dan akan berbeda apabila data diperoleh melalui wawancara.

\section{Saran}

Adapun saran peneliti untuk perusahaan kedepannya adalah (1) Metode penelitian selanjutnya dapat menggunakan metode wawancara untuk menguatkan bukti penelitin. (2) Menambahkan variabel lain dalam penelitian ini, seperti motivasi dan budaya organisasi

\section{DAFTAR PUSTAKA}

Agustin, Henri; Arza, Fefri Indra; Mulyani, Erly; Fitra, Halkadri. (2017). Potret Pertanggung Jawaban dan Pelaporan dan Keuangan Nagari di Kabupaten Pasaman Barat. Jurnal WRA. 5(2). 1019-1028.

Anthony, Robert N dan Vijay Govindarajan. 2007. Sistem Pengendalian Manajemen. Edisi Ke-11. Buku I. Jakarta. Salemba Empat

Amrizal.2004. Pencegah Fraud dan Pendeteksian Kecurangan Oleh Audit Internal .Alfabeta. Bandung

Ellwood. 1993. Praktek Penyelenggaraan Pemerintah di Daerah.Bima Aksara, Jakarta, 2001. https://antikorupsi.org/

https://www.kompasiana.com/adibermasa/5a426066bde5752cea708b02/jadi-perhatian-kpk-danadesa-di-sumbar-rawan-diselewengkan diakses tanggal 01 November 2018

https://www.harianhaluan.com/news/detail/66394/jaksa-kumpulkan-walinagari-selimapuluh-

kotadiakses tanggal 01 November 2018

Karyono, 2013.Forensic Fraud.Edisi I. Yogjakarta. ANDI

Kurnia, Indra. 2014. Pengaruh Sistem Akuntansi Keuangan Daerah dan Kualitas Aparatur Pemerintah Terhadap Akuntabilitas Keuangan. Vol 2 No 1 Tahun 2014. Seri C. Jurnal Ekonomi. UniversitasNegeri Padang

Mardiasmo, 2006. Perwujudan Transparasi dan Akuntabilitas Publik Melalui Akuntansi Sektor Publik :Suatu Sarana Good Governance. Jurnal Akuntansi Pemerintah. Diakses tanggal 05 November 2018

Sanuari, Nilam. 2014. Pengaruh system pengendalian intern, kesesuaian kompensasi dan moralitas manajemen terhadap kecendrungan kecurangan akuntansi. Vol 2 No 1 Tahun 2014 Seri D.Jurnal Ekonomi. Universitas Negeri Padang

Tunggal, Amin Widjaja. 1992. Pemeriksaan Kecurangan. Jakarta. Rhineka Cipta

Veithzal,Rivai.2005.Manajemen Sumber Daya Manusia Untuk Perusahaan Dari Teori ke Praktik .Edisi 1. PT Raja Grafindo Persada, Jakarta. 